OBJECTIVE: T lymphocytes have a central regulatory role in the pathogenesis of asthma. The objective of this study was to characterize immunologically the activation stage of asthma and the functional profile of lymphocytes from induced sputum, with particular emphasis on $\gamma \delta \mathrm{T}$ cells.

Methods: Induced sputum was collected from 10 patients with acute exacerbation of asthma, and from healthy controls. The expression of activation markers on freshly isolated induced sputum lymphocytes and T-cell subsets was analyzed by double immunofluorescent staining and flow cytometry. Fas ligand (FasL) was determined by reverse transcriptase-polymerase chain reaction analysis. The phenotype of $\gamma \delta$ T-cell subpopulations was tested by A13 and BB3 monoclonal antibodies. In this context, the functional profile of $\gamma \delta$ T cells was tested in a chromium releasing test.

Results: A significantly decreased proportion of $\alpha \beta T$ cells and an increased proportion of $\gamma \delta$ T cells, CD56 ${ }^{+}$ cells and $\mathrm{CD8}^{+} \gamma \delta \mathrm{T}$ cells were found in asthma patients compared with healthy controls. In asthmatic patients, there is a significantly increased proportion of $T$ cells expressing CD69 and CD25 antigen. After stimulation of $\gamma \delta \mathrm{T}$ cells, an increased expression of intracellular tumour necrosis factor- $\alpha$, interleukin (IL)- 4 and IL10 cytokines were found at higher levels than controls. Interferon- $\gamma$ was observed at similar levels in asthma patients and healthy controls. Freshly isolated T-cell receptor (TCR) $\gamma \delta^{+}$cells exhibited an increased percentage of FasL in our patient group. FasL mRNA was detected in TCR $\gamma \delta^{+}$cells before and after IL2 stimulation. TCR $\gamma \delta^{+}$cells were cytotoxic against the $\mathrm{K} 562$ cell line. This natural killer activity was mediated by the A13-positive subpopulation.

Conclusion: The presence of cytokines producing $\gamma \delta$ cells in induced sputum of asthmatic patients is consistent with regulatory activities. These cells display also cytotoxic function.

Key words: Asthma, $\gamma \delta \mathrm{T}$ cells, Inflammation, Fas ligand, Cytokines

\section{T cells expressing the $\gamma \delta$ receptor are essential for Th2-mediated inflammation in patients with acute exacerbation of asthma}

\author{
Agnès Hamzaoui ${ }^{1}$, Alice Kahan ${ }^{2}$, Khaled Ayed ${ }^{3}$ and \\ Kamel Hamzaoui ${ }^{4, C A}$
}

${ }^{1}$ Department of Paediatric and Respiratory Diseases, A. Mami Hospital, Pavillon B, 1082 Aciana, Tunisia; 2Immunopathology Laboratory, Ch. Nicolle Hospital; ${ }^{3}$ INSERM, Cochin Hospital, Paris, France; and ${ }^{4}$ Immuno-Histology Laboratory, Medicine University of Tunis, 9 rue Z. Essafi, 1007 Tunis, Tunisia

\footnotetext{
${ }^{\mathrm{CA}}$ Corresponding Author Fax: +21671569427 E-mail: Kamel.Hamzaoui@fmt.rnu.tn
}

\section{Introduction}

Asthma is characterized by a chronic mucosal inflammation of the airways, which underlies the two main clinical features of the disease: bronchial constriction and bronchial hyper-responsiveness. The mechanisms regulating airway function are complex and still poorly understood. In diseases such as asthma, involvement of immune-dependent mechanisms has been suggested in causing changes in airway responsiveness to bronchoconstrictors. The role of $\mathrm{T}$ lymphocytes in the pathogenesis of asthma has been emphasized in recent years. $T$ lymphocytes are increased in asthma and are activated in the bronchial mucosa of the asthmatics. ${ }^{1}$ Through secretion of cytokines, $\mathrm{CD}^{+} \mathrm{T}$ lymphocytes actively participate to the inflammatory process found in asthma. ${ }^{2} \gamma \delta \mathrm{T}$ cells can regulate airway function in an $\alpha \beta$ T cell-independent manner, identifying them as important cells in pulmonary homeostasis. $\gamma \delta \mathrm{T}$ cells can produce $\mathrm{T}$ helper (Th)2 cytokines, which suggests their possible participation in the development of Th2 responses and, thus, in the onset of pulmonary allergic reactions. ${ }^{2}$ In a model of pulmonary allergic inflammation, genetically $\gamma \delta$ T-cell-deficient mice exhibited low specific immunoglobulin (Ig)E and interleukin (IL)-5 release, and diminished T-cell infiltration compared with wild-type mice. These response were restored by 
administration of IL- $4 .{ }^{3}$ Thus, $\gamma \delta \mathrm{T}$ cells are essential for inducing IL- 4 secretion and Th2-mediated airways inflammation. ${ }^{3}$ Activation of the regional $\gamma \delta$ T cells to produce lymphokines would then promote nonspecific inflammation and macrophage activation, providing a degree of non-specific resistance. ${ }^{4,5}$ However, the precise role of $\gamma \delta \mathrm{T}$ lymphocytes in the human lung and lower airways ${ }^{6}$ is not yet known. $\gamma \delta$ $\mathrm{T}$ cells home in the epithelial surface, ${ }^{7,8}$ and induced sputum should be representative for $\gamma \delta \mathrm{T}$ cells in inflamed bronchi. Numerous effector functions have been attributed to $\gamma \delta$ cells, ${ }^{8}$ and we are only now uncovering their potentially important contributions to immune responses.

The objective of this investigation was to determine whether there is a shift in the proportion of $\gamma \delta \mathrm{T}$ cells and their function in induced sputum of patients with asthma as compared with healthy controls.

\section{Patients and methods}

\section{Patients}

Induced sputum samples were collected from 10 successive patients with allergic asthma. All were inpatients, admitted by the emergencies for an acute exacerbation of dyspnea (mean age, 38.5 years; range, 22-80 years). Patient asthma was classified according to National Heart, Lung and Blood Institute criteria ${ }^{9}$ as persistent mild-to-moderate asthma. The sample was obtained the day after their admission. A precise history of the patient was subsequently obtained and, after recovery functional respiratory tests, skin tests and serum IgE dosages were realized. Patients were excluded due to the following: concomitant infectious pneumonia, tuberculosis, interstitial lung diseases, bronchiectasis, lung cancer, and associated acute pathologies: cardiac, renal, liver, or neurological diseases. Ten healthy subjects (mean age, 28.7 years; range, 22-36 years), who had normal pulmonary radiographs and showed no clinical signs of respiratory diseases, acted as controls. Informed consent was obtained from all the patients. The study was approved by the local Ethics Committee.

\section{Sputum}

Sputum induction and processing were realized following the method recently reported. ${ }^{10}$ Briefly, after the inhalation of salbutamol $(2 \times 200 \mu \mathrm{g})$, subjects were asked to inhale sterile, pyrogen-free, hypertonic saline in increasing concentrations for a duration of $10 \mathrm{~min}$. Most patients were able to expectorate an adequate sample $(5 \mathrm{ml}$ and more) within the first $10 \mathrm{~min}$. The cell pellet was resuspended in phosphate-buffered saline (PBS) in a volume equal to the sputum plus dithiothreitol solution volume. Total cell counting was carried out in a haemocytometer and the cell concentration was adjusted to $1.0 \times 10^{6} \mathrm{cells} / \mathrm{ml}$. Cytospins were prepared by adding $75 \mu \mathrm{l}$ of cell suspension into Shandon II cytocentrifuge cups (Shandon Southern Instruments, UK) and spun for $8 \mathrm{~min}$ at $500 \mathrm{rpm}$.

\section{Monoclonal antibodies}

Monoclonal antibodies (MoAbs) against human CD69, CD40 ligand and $\gamma \delta$ T-cell receptor (TCR) were all from Coulter Electronics, Luton, UK. Fluorescein isothiocyanate (FITC)-labelled and unlabelled MoAbs against human $\alpha \beta$ TCR (clone WT31), FITC-labelled MoAbs against human $\gamma \delta$ TCR, and PE-labelled MoAbs against human CD4 and CD8 were all purchased from Becton Dickinson (Oxford, UK). MoAbs against human CD25 and FITC-labelled MoAbs against human CD56 were purchased from Immunotech (Marseille, France). Phycoeritrin (PE)-labelled or FITC-labelled goat antimouse immunoglobulin, the $\mathrm{F}(\mathrm{ab})_{2}$ fragments, were purchased from Dako (Marseille, France). MoAbs anti-

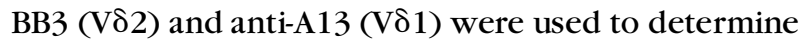
anti- $\gamma \delta$ TCR subpopulations. Optimal dilutions for use in immunofluorescence procedures were established in preliminary experiments.

\section{Double immunofluorescence staining}

To analyse expression of activation markers on induced sputum lymphocytes and T-cell subsets, $2 \times$ $10^{3}$ freshly isolated cells in $100 \mu$ of staining buffer (PBS with $1 \%$ foetal calf serum (FCS) and $0.02 \% \mathrm{NaN}_{3}$ ) were incubated with $5 \mu 1$ of MoAbs against CD25 or CD40L, or $30 \mu 1$ of MoAbs against CD69, for $45 \mathrm{~min}$ on ice. Then the cells were washed twice with $1 \mathrm{ml}$ of staining buffer at $160 \times g$ for $5 \mathrm{~min}$ at $4^{\circ} \mathrm{C}$, and subsequently incubated with $100 \mu \mathrm{l}$ of PE-labelled goat anti-mouse immunoglobulin, diluted 1:100, for $30 \mathrm{~min}$ on ice, followed by washes as earlier. Unbound goat antibody sites were blocked by incubating the cells with $100 \mu$ l of PBS containing $10 \%$ normal human serum for $10 \mathrm{~min}$ on ice before the cells were incubated with $10 \mu$ l of FITC-labelled MoAbs against $\alpha \beta$ or $\gamma \delta$ TCR or FITC-labelled control mouse IgG1. The cells were washed as before and fixed in $200 \mu$ of $1 \%$ paraformaldehyde in staining buffer. For co-receptor measurements, $2 \times 10^{3}$ cells were incubated for $45 \mathrm{~min}$ on ice with $10 \mu \mathrm{l}$ of PElabelled MoAbs against CD4 or CD8 or PE-labelled control mouse IgG1, and $10 \mu 1$ of FITC-labelled antibodies against CD $56, \alpha \beta$ TCR, or $\gamma \delta$ TCR or FITClabelled control mouse IgG1.

\section{Cell culture}

Cells were washed in RPMI medium and either stained immediately or cultured before further analysis. Cells were cultured in 24-well plates at a concentration of $1 \times 10^{3}$ cells $/ \mathrm{ml}$ in RPMI medium 
with $10 \% \mathrm{FCS}$ for $12 \mathrm{~h}$ at $37^{\circ} \mathrm{C}, 5 \% \mathrm{CO}_{2}$. Cells were cultured in the presence of phytohaemagglutinin (PHA) (Sigma Chemical Co., St Louis, MO, USA) at a concentration of $5 \mu \mathrm{g} / \mathrm{ml}$ or in the presence of phorbol myristrate (PMA) (Sigma Chemical Co.) at a concentration of $50 \mathrm{ng} / \mathrm{ml}$ in combination with $1 \mu \mathrm{mol} / \mathrm{ml}$ of ionomycin (Sigma Chemical Co.) at $10 \mu \mathrm{g} / \mathrm{ml}$. To prevent secretion of the cytokines, brefeldin A at $10 \mu \mathrm{g} / \mathrm{ml}$ (Sigma Chemical Co.) was added during the last $4 \mathrm{~h}$ of the incubation. Maximum production of interferon- $\gamma$ (IFN- $\gamma$ ) and tumour necrosis factor- $\alpha$ (TNF- $\alpha$ ) was observed after stimulation with PMA in combination with ionomycin, whereas PHA was more effective in inducing production of IL4 and IL-10.

\section{Intracellular cytokines}

Stimulated and unstimulated cells were stained in parallel by incubating $2 \times 10^{3}$ cells in $100 \mu \mathrm{l}$ of staining buffer for $45 \mathrm{~min}$ on ice with $10 \mu \mathrm{l}$ of MoAbs against a $\gamma \delta$ TCR, diluted 1:10, followed by $100 \mu$ of FITC-labelled goat anti-mouse immunoglobulin, diluted 1:100, for $30 \mathrm{~min}$ on ice. Before the second staining, the cells were fixed in $200 \mu \mathrm{l}$ of $4 \%$ paraformaldehyde in PBS for 10 min on ice and then unbound goat antibody sites were blocked by incubating the cells with $100 \mu$ l of PBS containing 5\% normal human serum and 5\% normal mouse serum for $10 \mathrm{~min}$ on ice. To permeabilize the cells, $0.1 \%$ saponin was included in the staining buffer used for subsequent incubations and washing. The cells were incubated with $10 \mu \mathrm{l}$ of PE-labelled antibodies against cytokines (IL4, IL-10, TNF- $\alpha$ or IFN- $\gamma$ ) or PE-labelled control mouse IgG1, diluted 1:20, for $45 \mathrm{~min}$ on ice, washed and then fixed in $400 \mu$ l of 1\% paraformaldehyde in staining buffer.

\section{Flow cytometric analysis}

Fluorescent labelled cells were analysed by a flow cytometry (FACScan; Becton Dickinson). Before each set of data analysis, the machine was standardized for data reproducibility using fluorescent labelled beads (Coulter). Ten thousand cells were collected. Plots showing the size and granularity were used to select the lymphocyte population for further analysis. Cells stained with isotype-matched antibody or a second antibody alone were used as controls, with positive cells set at $0.5 \%$. For intracellular cytokine analysis, unstimulated cells were used as negative controls.

\section{Natural killer activity}

$\gamma \delta$ T-cell cytotoxic activity was tested against K562 target cells in a standard $4-\mathrm{h}{ }^{51} \mathrm{Cr}$-release assay. Briefly, $\gamma \delta \mathrm{T}$ cells in RPMI-1640 containing $10 \%$ FCS at $37^{\circ} \mathrm{C}$ for $48 \mathrm{~h}$ were used as effector cells, incubated with IL-
2, anti-Fas, anti-BB3 or anti-A13 monoclonal antibodies. The cells were washed and assayed for cytotoxic activity against ${ }^{51} \mathrm{Cr}$-labelled target cells in a total volume of $200 \mu \mathrm{l}$ in 96-well U-bottom microtitre plates. After $4 \mathrm{~h}, 100 \mu \mathrm{l}$ of supernatant were harvested and counted in a gamma-counter (LKB, Bromma, Sweden). Maximum and spontaneous releases were determined by incubating ${ }^{51} \mathrm{Cr}$-labelled target cells with 1\% Triton-X-100 (Sigma Chemical Co.) or medium alone, respectively. All determinations were made in duplicate, and effector:target (E:T) ratios ranged from 10:1. The percentage of specific lysis was determined as follows: [(experimental release - spontaneous release)/(maximum release - spontaneous release)] $\times 100$. The spontaneous release was routinely less than $10 \%$ of the maximum release.

\section{Statistical analysis}

Results are expressed as mean \pm standard error of the mean for each study group. Significance was evaluated using Student's $t$-test for non-paired samples with unequal variance, with $p<0.05$ being regarded as significant.

\section{Results}

Expression of $\alpha \beta$ TCR, $\gamma \delta$ TCR, CD56, CD 4 and CD8 on lymphocytes and T-cell subsets in induced sputum cells from patients with asthma and from healthy controls

The expression of $\alpha \beta$ TCR, $\gamma \delta$ TCR, CD56, CD 4 and CD8 on lymphocytes was analysed in induced sputum from patients with acute exacerbation of asthma and from healthy controls (Fig. 1). A significant decrease in the proportion of lymphocytes expressing $\alpha \beta$ TCR and a significant increase in the proportion of lymphocytes expressing $\gamma \delta$ TCR or CD56 were found

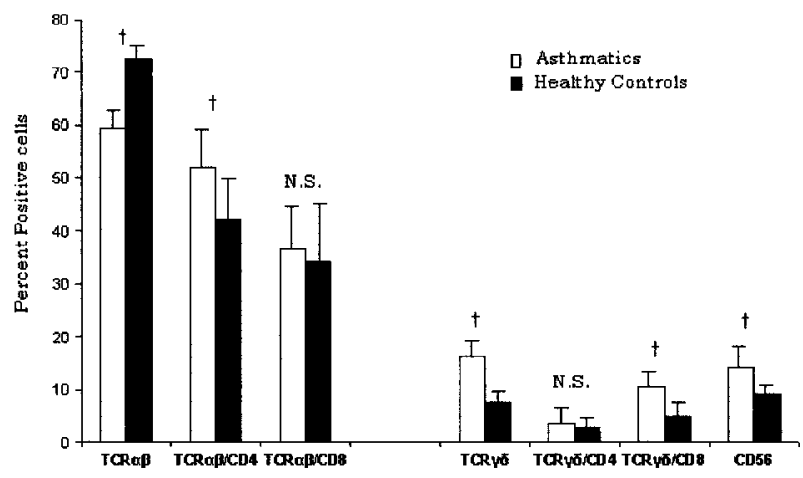

FIG. 1. Expression of TCR $\alpha \beta$, TCR $\gamma \delta$, CD4, CD8, and CD56, analysed by immunofluorescence staining and flow cytometry. Results are expressed as percentage positive cells, shown as mean \pm standard error of the mean for induced sputum from 10 asthmatic patients with acute exacerbation of asthma and from 10 healthy controls. $t$ Significantly different between asthmatic patients and healthy controls ( $p$ $<0.001$ ); N.S., not significantly different. 
in asthma patients $(59.4 \pm 3.4 \%, 16.2 \pm 1.3 \%$, and 14.2 $\pm 2.7 \%$, for $\alpha \beta$ TCR, $\gamma \delta$ TCR and CD 56 , respectively) compared with healthy controls $(72.5 \pm 2.6 \%, p<$ $0.05 ; 7.4 \pm 0.5 \%, p<0.005$; and $9.2 \pm 0.4 \%, p<0.005$, for $\alpha \beta$ TCR, $\gamma \delta$ TCR and CD56, respectively), as shown in Fig. 1.

The proportion of $\mathrm{CD}^{+}$lymphocytes was raised in induced sputum of patients with asthma $(52 \pm 7.8 \%$, $p<0.01)$ compared with controls $(42 \pm 3.2 \%)$. There was no difference in the percentage of $\mathrm{CD}^{+}$lymphocytes between asthma patients $(36.5 \pm 8.2 \%, p<0.01)$ and the control group $(34 \pm 10.4)$ in induced sputum.

When the T-cell subsets were analysed separately, a significantly raised proportion of $\gamma \delta \mathrm{T}$ cells from asthma patients $(10.5 \pm 1.2 \%)$ co-expressed CD8 compared with $\gamma \delta \mathrm{T}$ cells from healthy controls (4.9 \pm $3.4 \%, p<0.01$ ) (Fig. 1).

We analyzed the TCR $\gamma \delta^{+}$cells subsets $\left(\mathrm{A} 13^{+}\right.$cells and $\mathrm{BB}^{+}$cells). The significant increase in induced sputum of TCR $\gamma \delta^{+}$cells in patients with asthma, compared with normal controls, was exclusively due to the increase of the $\mathrm{A} 13^{+}$subset (asthma patients:

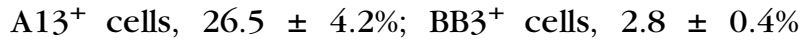
versus control: ${\mathrm{A} 13^{+}}^{+}$cells, $4.4 \pm 1.2 \%$; $\mathrm{BB} 3^{+}$cells, 5.2 $\pm 1.2 \%)$.

\section{Expression of activation markers on T cells in} induced sputum from patients with asthma

A significantly increased percentage of $\mathrm{CD}^{+} 9^{+}$lymphocytes was observed in the induced sputum from asthmatic patients $(15.3 \pm 2.4 \%)$ compared with the controls $(6.5 \pm 1.7 \%, p<0.01)$.

An increase was observed for the proportion of $\gamma \delta$ $\mathrm{T}$ cells expressing CD25 in patients with asthma (12.3 $\pm 2.6 \%, p<0.01)$ compared with healthy controls $(2.5 \pm 1.8 \%)$.

\section{Expression of intracellular cytokines on $\gamma \delta \mathrm{T}$ lymphocytes in induced sputum from patients with asthma}

The expression of intracellular IL- 4 , IL-10, IFN- $\gamma$ and TNF- $\alpha$ in the $\gamma \delta$ T-cell subset was analysed in induced sputum from patients with acute exacerbation of asthma and from healthy controls (Fig. 2).

Before stimulation, $\gamma \delta \mathrm{T}$ cells did not express any of the cytokines analysed. However, after appropriate mitogen stimulation of $\gamma \delta \mathrm{T}$ cells, there was expression of intracellular TNF- $\alpha$, IFN- $\gamma$, IL- 4 and IL-10 cytokines (Fig. 2). A significantly increased proportion of $\gamma \delta \mathrm{T}$ cells from asthma patients could be induced to express TNF- $\alpha$ after PHA stimulation compared with controls $(p<0.05)$. A similar proportion of $\gamma \delta \mathrm{T}$ cells expressing IFN- $\gamma$ was observed for the asthma patients and the controls. The frequency of $\gamma \delta \mathrm{T}$ cells expressing IL-4 or IL-10 was significantly increased in

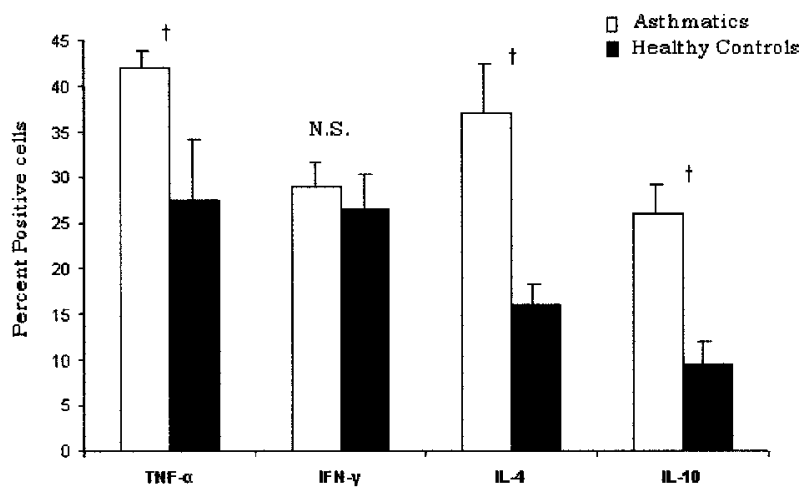

FIG. 2. Expression of TNF- $\alpha$, IFN- $\gamma$, IL-4 and IL-10, on induced sputum $\gamma \delta \mathrm{T}$ cells in asthmatic patients and in healthy controls analysed by double immunofluorescent staining and flow cytometry. $t$ Significantly different between asthmatic patients and healthy controls $(p<0.001)$; N.S., not significantly different.

asthma patients when compared with induced sputum from healthy controls.

\section{Phenotype and expression of Fas ligand mRNA} in TCR $\gamma \delta^{+}$cells

Freshly isolated TCR $\gamma \delta^{+}$cells isolated from induced sputum exhibited a high percentage of Fas ligand (FasL) in patients with acute exacerbation of asthma $(14.7 \pm 4.5 \%, p<0.01)$, when compared with healthy controls $(3.6 \pm 2.8 \%)$.

When TCR $\gamma \delta^{+}$cells from asthma patients and healthy controls were IL-2-activated, they expressed FasL mRNA (Fig. 3). This finding support the view that TCR $\gamma \delta^{+}$cells from asthma patients have the ability to lyse Fas-expressing targets by producing FasL, without IL-2 activation.

Functional profile of TCR $\gamma \delta^{+}$cells in induced sputum

Isolated induced sputum TCR $\gamma \delta^{+}$cells from eight patients with asthma compared with five healthy

Healthy controls Asthmatic patients

\begin{tabular}{|cc|cc|}
\hline$-\mathrm{IL}-2$ & $+\mathrm{IL}-2$ & $-\mathrm{IL}-2$ & $+\mathrm{IL}-2$ \\
1 & 2 & 3 & 4
\end{tabular}

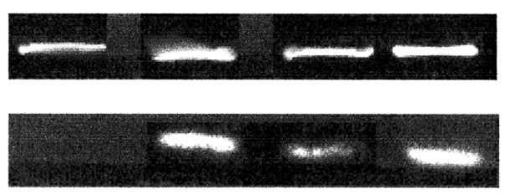

$\beta 2$ microglobulin

FIG. 3. Expression of FasL mRNA on TCR $\gamma \delta^{+}$cells in induced sputum from patients with asthma. The expression of FasL and $\beta 2$ microglobulin in freshly isolated TCR $\gamma \delta^{+}$cells (lane 1 and lane 3$)$, and TCR $\gamma \delta^{+}$cells activated with IL-2 $(250 \mathrm{U} / \mathrm{ml})$ (lane 2 and lane 4), were analysed by reverse transcriptasepolymerase chain reaction as described in Materials and methods. Representative data from two experiments are shown. 


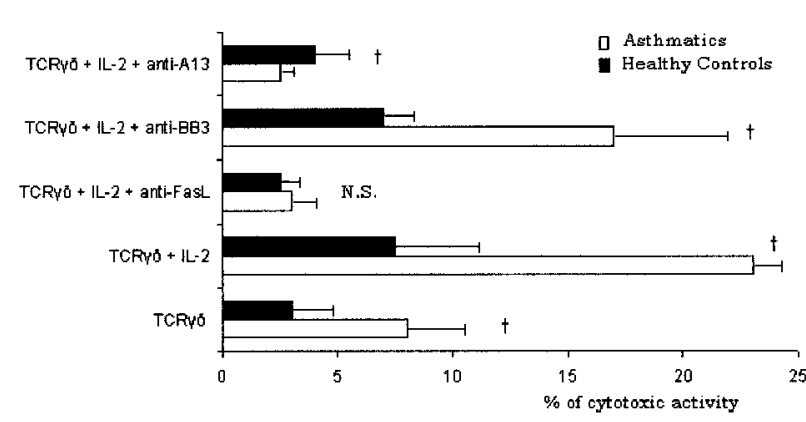

FIG. 4. Cytotoxic activity mediated by TCR $\gamma \delta^{+}$cells against K562 target cells. TCR $\gamma \delta^{+}$cells were purified from induced sputum from asthmatic patients and from healthy controls. The values represent the mean of triplicate assays at a 10:1 $(E: T)$ ratio. + Cytotoxic activity of asthmatics was significantly different from healthy controls $(p<0.001)$; N.S., not significantly different.

controls were tested for their cytotoxic activity against K562 cell line at a ratio of 10:1 (E:T) (Fig. 4). Fresh TCR $\gamma \delta^{+}$gave low but detectable cytotoxic activity in asthma patients $(8 \pm 2.5 \%)$, which was $<5 \%$ in healthy controls. When TCR $\gamma \delta^{+}$cells were cultured with IL-2 for 3 days, cytotoxic activity appeared in healthy controls $(7.5 \pm 4 \%)$ and increased significantly in patients with asthma $(23 \pm 2.4 \%, p<0.001)$.

Cytotoxic activity of IL-2-activated TCR $\gamma \delta^{+}$cells was abolished when anti-FasL was added. Cytotoxicity was lower than $5 \%$ both in asthmatic patients and in healthy controls.

When IL-2-activated TCR $\gamma \delta^{+}$cells were incubated with anti-BB3 monoclonal antibody, natural killer (NK) activity decreased, compared with IL-2-activated TCR $\gamma \delta^{+}$cells alone in asthmatic patients, but did not reach statistical significance. Anti-BB3 monoclonal antibody did not reduce the lytic activity of IL2-activated TCR $\gamma \delta^{+}$cells in healthy controls.

However, the addition of anti-A13 monoclonal antibody to activated-TCR $\gamma \delta^{+}$cells induced the abolition of cytotoxic activity both in asthmatics and in healthy controls, which was lower than 5\%. Lytic activity in healthy controls was identical to TCR $\gamma \delta^{+}$ cell activity alone. In asthmatics, anti-A13 monoclonal antibody inhibited NK activity at a lower level than inactivated TCR $\gamma \delta^{+}$cells.

\section{Discussion}

We have observed a reduced number of $\alpha \beta$ TCR and an increased number of $\gamma \delta \mathrm{T}$ lymphocytes in induced sputum from patients with acute asthma exacerbation. Studies revealed that the expression of $\alpha \beta$ TCR by alveolar $\mathrm{T}$ cells was decreased as compared with autologous blood $\mathrm{T}$ cells, in a wide variety of pathological and physiological conditions of the lung. ${ }^{11}$ The expression of CD3 antigen by alveolar T cells is also likewise reduced in health and disease. ${ }^{12,13}$ We analysed the activation status, cytokine production and cytotoxic function of $\gamma \delta \mathrm{T}$ cells in induced sputum compared with those found in healthy controls.

The proportion of $\gamma \delta$ T cells in BAL from patients with asthma was expanded as has been shown by Molfino et al. ${ }^{4}$ Asthma patients had a raised percentage of $\mathrm{CD}^{+} \mathrm{T}$ cells among the cells expressing the $\gamma \delta$ TCR. This suggests a role for $\mathrm{CD}^{+}$cells in asthma disease, with the $\gamma \delta \mathrm{T}$ cells being more prominent in asthma-induced sputum. It has been reported that, in allergic asthmatic subjects, T-cell expansion preferentially emerges in the lung $\mathrm{CD}^{+}$ T-cell subset in BAL, with direct attention to the role of CD8 $\mathrm{T}$ lymphocytes in the pathogenesis of asthma. ${ }^{11}$ Furthermore, we reported a significant increase in the proportion of $\mathrm{CD} 56^{+}$cells in sputum from asthma patients compared with controls. CD56 is one of the markers of NK cells. The involvement of cytotoxicity in asthma pathways has been suggested, by the finding of induced sputum $\gamma \delta \mathrm{T}$ cells expressing increased percentages of CD56 and CD8 markers.

Studies that aimed at determining expansion of the $\gamma \delta$ T-cell population in the human lung are scarce. Groh et al. ${ }^{14}$ did not detect $\gamma \delta \mathrm{T}$ cells in foetal and adult lung using MoAbs. Walker et al. ${ }^{15}$ found no difference in the number of $\gamma \delta \mathrm{T}$ cells between asthmatic and control subjects, which is in accordance with the findings of Fajac et al. ${ }^{16}$ in the normal bronchi mucosa and in alveolar parenchyma. ${ }^{17}$ Conversely, Spinozzi et al. ${ }^{18}$ reported an increased number of $\gamma \delta \mathrm{T}$ cells in asthmatic patients, which is in accordance with our finding. Agostini et al. ${ }^{19}$ recently reported that $\mathrm{V} \delta 2^{+} \mathrm{T}$ cells comprise approximately $70 \%$ of the $\gamma \delta \mathrm{T}$ cells in the normal lung. It has been reported that the number of $\gamma \delta \mathrm{T}$ lymphocytes in bronchi biopsies of asthmatics was not different from controls. ${ }^{20}$ These different results might be due to the diversity of the patients studied, since the airway inflammation may vary with the severity of the disease. An increased number of $\gamma \delta \mathrm{T}$ cells were found in the nasal mucosa of patients with perennial allergic rhinitis. $^{21} \gamma \delta \mathrm{T}$ cells may exist either in deep layers of the airway wall or in some distal bronchi. It is also of interest that the presence of $\gamma \delta$ T cells appears to be restricted to early stages of infection or inflammation. ${ }^{22,23}$ The increased $\gamma \delta \mathrm{T}$ cells found in this work could be associated with the acute symptoms observed in our patients and to the use of induced sputum, which describes a real representative finding of the cellularity distribution in the proximal bronchi. Yet in none of the bibliographic studies was the functional status of such cells investigated.

$\gamma \delta \mathrm{T}$ cells are considered to be pre-activated $\mathrm{T}$ cells in BAL of asthma patients. ${ }^{4}$ A classical way of analysing T-cell activation is to measure the upregulation of CD25, the $\alpha$-chain of the IL- 2 receptor. In asthma patients, it was clear that the $\gamma \delta$ T-cell population was in an activated stage, whereas the $\alpha \beta$ 
T-cell subset showed no increase in CD25 expression compared with controls. This observation indicates that the $\gamma \delta$ T cells in sputum from asthma patients had already been activated. Whether the activation occurs as a result of the disease or whether the activated $\gamma \delta$ $\mathrm{T}$ cells play a direct role in the pathogenesis needs to be elucidated.

It was of interest to investigate the expression of another activation molecule on the $T$ cells that could interact with the various cells and epithelial proteins in the bronchial mucosa. Therefore, we analysed the expression of CD69. Our study found a raised percentage of $\gamma \delta \mathrm{T}$ cells expressing CD69 in asthma patients compared with controls. CD69, an early activation marker, is involved in lymphocyte proliferation, and functions as a signal-transmitting receptor in $\mathrm{T}$ and $\mathrm{B}$ lymphocytes, NK cells and platelets. ${ }^{24}$ The ligand for CD69 is still unknown.

Unbalanced expression of Th1 or Th2 cytokines has been associated with asthma and may play a role in human inflammatory diseases. Previous studies analysing cytokines in asthma have not been directed against individual cells, but have analysed cytokines in serum or in supernatants from bulk populations of peripheral blood, BAL, or induced sputum. ${ }^{3,25,26}$ The development of a method of detecting intracellular cytokines by flow cytometry meant that it was possible to study the contribution of individual cells, in a heterogeneous cell population, to specific cytokine production. Asthma patients group had an increased sputum proportion of $\gamma \delta \mathrm{T}$ cells secreting TNF- $\alpha$ when compared with healthy controls. TNF- $\alpha$ is another cytokine involved in inflammation that plays a major role in induction of adhesion molecules and inflammatory cytokine production. ${ }^{27}$ It is mainly produced by activated monocytes and macrophages. Our results show, however, that in asthma patients a substantial proportion of $\gamma \delta \mathrm{T}$ cells is able to participate in TNF- $\alpha$ production. The observation of an increased proportion of $\gamma \delta \mathrm{T}$ cells that secrete TNF$\alpha$ provides an interesting finding in asthma.

Our results reported increased IL- 4 and IL-10 intracellular cytokines expression. This corroborates the recent inflammatory response in induced sputum in patients with acute exacerbation of asthma. ${ }^{3}$ Thus, Th 2 cytokine-producing cells of the $\gamma \delta$ TCR type are present in asthmatic sputum patients. These Th2 cytokine-producing cells may be upregulated as part of the general inflammatory response in the asthmatic bronchi. Th1 cytokines were at a normal level compared with controls.

Our findings reported a significant increase of $\gamma \delta \mathrm{T}$ cells associated with a non-specific lysis against the K562 cell line. One of the mechanisms of cellmediated cytotoxicity established is the Fas/FasL system. Recent studies reported that NK cells in the inflammatory sites operate through the Fas/FasL interaction, and that FasL was expressed in the inflammatory sites. ${ }^{28}$ Interestingly mononuclear cells co-expressed both Fas and FasL, suggesting that Fas/ FasL interactions may function in not only a paracrine way, but also an autocrine way. This may be relevant to the abnormal immune response in diseases. ${ }^{29}$

The earliest contact between antigen and the innate immune system is thought to direct the subsequent antigen-specific T-cell response. It has been hypothesized that cells of the innate immune system, such as NK cells, NK1.1-positive T cells, and $\gamma \delta \mathrm{T}$ cells, may regulate the development of allergic airway disease. ${ }^{30}$ It has been demonstrated that depletion of NK cells before immunization inhibits pulmonary eosinophil and CD3-positive T-cell infiltration as well as increased levels of IL-4, IL-5, and IL-12 in bronchoalveolar lavage fluid in a murine model of allergic asthma. ${ }^{31}$

We have reported that cells from induced sputum from patients with asthma exhibited an increased $\mathrm{CD} 6^{+}$cells within the $\gamma \delta \mathrm{T}$-cell population, which in the majority is composed of $\mathrm{A} 13^{+}$cells. NK activity in sputum from patients with asthma was mediated by $\mathrm{A} 13^{+}$cells. The propensity of $\mathrm{A} 13^{+} \gamma \delta \mathrm{T}$ cells to accumulate in the airway of patients with asthma could be due to the better migratory capacities of these cells, as reported in other investigations. ${ }^{32,33} \mathrm{An}$ increase of ${\mathrm{A} 13^{+}}^{+}$cells has been described in other inflammatory sites; it represents the major fraction of intraepithelial $\mathrm{T} \gamma \delta^{+}$in the synovial fluid in rheumatoid arthritis. ${ }^{34}$ It was also reported in cerebrospinal fluid, and in bronchoalveolar lavage of patients with active Beh et's disease. ${ }^{35}$ The present results report that $\mathrm{A}_{13}{ }^{+}$cells within the $\mathrm{T} \gamma \delta$ population acted as cells mediating NK activity, in sputum from patients with asthma.

The present study revealed that the expression levels of FasL mRNA was high. Similar results were found in the liver, ${ }^{35}$ and the authors reported that this situation is compatible with the conclusion that the high level of autologous killing in $\mathrm{TCR}^{\mathrm{int}}$ cells is mediated by FasL/Fas molecules, but not perforin. The FasL-mediated cytotoxicity may be acquired at more mature stages of NK-cell maturation. ${ }^{36}$

An interesting recent study from Zuany-Amorin $e t$ $a l .{ }^{3}$ reported that the subset of $\gamma \delta \mathrm{T}$ cells directly involved in IL- 4 production will represent an important step for understanding and modulating the development of Th2 responses, particularly in the context of allergic diseases such as bronchial asthma. A subset of $\gamma \delta \mathrm{T}$ cells, positive for A13 monoclonal antibody, in sputum from asthmatics acted as NK cells through the FasL interaction. The knowledge of $\gamma \delta$ T-cell function and specificity appears to be an important component of asthma. $\gamma \delta \mathrm{T}$ cells have proven biological activity in the lung. ${ }^{8}$ We therefore hypothesize that $\gamma \delta$ T-cell activity elicited by infection early in life accelerates the bias in $\gamma \delta$ T cells away for Th2. ${ }^{8}$ 


\section{References}

1. Bradley BL, Azzawi M, Jacobson M, Assoufi B, Collins JV, Irani AM Schwartz LB, Durharn SR, Jeffrey PK, Kay AB. Eosinophils, T-lymphocytes, mast cells, neutrophils, and macrophages in bronchial biopsy specimens from atopic subjects with asthma: comparison with biopsy specimens from atopic subjects without asthma and normal control subjects and relationship to bronchial hyper-responsiveness. $J$ Allergy Clin Immunol 1991; 88: 661-674

2. Robinson D, Hamid Q, Bentley A, Ying S, Kay AB, Durham SR. Activation of $\mathrm{CD}^{+} \mathrm{T}$ cells, increased TH2-type cytokine mRNA expression, and eosinophil recruitment in, bronchoalveolar lavage after allergen inhalation challenge in patients with atopic asthma.J Allergy Clin Immunol 1993; 92: 313-324.

3. Zuany-Amorin C, Ruffé C, Hailé S, Vargaftig B, Rereira P, Pretolani M. Requirement for $\gamma \delta \mathrm{T}$ cells in allergic airway inflammation. Science 1998 ; 280: $1265-1267$.

4. Molfino NA, Doherty PJ, Suurmann IL, Yang SX, Kesten S, Chapman KR, Slutsky AS. Analysis of the T cell receptor $\mathrm{V} \gamma$ region gene repertoire in bronchoalveolar lavage (BAL) and peripheral blood of atopic asthmatics and healthy subjects. Clin Exp Immunol 1996; 104: 144-153.

5. Res P, Thole J, de Vries R. Heat-shock proteins and autoimmunity in humans. Spring Semin Immunopatbol 1991; 13: 98-102.

6. Bienenstock J, Holt PG. Local immunity of the airways. Am Rev Respir Dis 1992; 146: 1351-1353.

7. Corrigan CJ, Kay AB. T cells and eosinophils in the pathogenesis of asthma. Immunol Today 1992; 13: 501-507.

8. Hayday AC, Roberts S, Ramsburg E. $\gamma \delta$ cells and the regulation of mucosal immune responses. Am J Respir Crit Care Med 2000; 162: S161-S163.

9. National Heart Lung and Blood Institute. International Consensus report on diagnosis and treatment of asthma. Eur Respir J 1992; 5: 601-641.

10. Hamzaoui A, Ben Brahim M, Zhioua A, Ayed Kh, Hamzaoui K. Inflammatory response in induced sputum mononuclear cells from patients with acute exacerbation of asthma. Mediat Inflamm 2000; 9: 131-37.

11. Wahlström J, Dahlën B, Ihre E, Wigzell $\mathrm{H}$, Grunewald J, Eklund A. Selective $\mathrm{CD}^{+} \mathrm{T}$ cells accumulate in the lung of patients with allergic asthma after allergen bronchoprovocation. Clin Exp Immunol 1998 112: 1-9.

12. Yamaguchi E, Itoh A, Furuya K, Nizowa N, Ohnuma N, Kodama N, Kpjima J, Kawakami Y. Reduced expression of alpha beta T-cell antigen receptor by alveolar T cells. Eur Respir J 1999; 13: 814-819.

13. Yamaguchi E,Okazaki N, Itoh A, Abes S, Kawakami Y. Modulation of accessory molecules on lung T cells. Chest 1990; 97: 1393-1400.

14. Groh V, Percelli SA, Fabbi M, Lanier LL, Picker LJ, Anderson T, Warnke RA, Bhan AT, Strominger JL, Brenner MB. Human lymphocytes bearing T cell receptor $\gamma / \delta$ are phenotypically diverse and evenly distributed throughout the lymphoid system. J Exp Med 1989; 169: 1277-1294.

15. Walker C, Kaegi M, Braun P, Blaser K. Activated T cells and eosinophils in bronchoalveolar lavage from subjects with asthma correlated with disease severity. J Allergy Clin Immunol 1991; 88: 935-942.

16. Fajac I, Roiqman GL, Lacronique J, Polla BS, Dusser DJ. Bronchial $\gamma \delta$ T-lymphocytes and expression of heat shock proteins in mild asthma. Eur Respir J 1997; 10: 633-638

17. Fajac I, Tazi A, Hance AJ, Bouchonnet F, Riquet M, Battesti G, Soler P. Lymphocytes infiltrating normal human lung carcinomas rarely express gamma delta T cell antigen receptors. Clin Exp Immunol 1992; 87: 127-131.

18. Spinozzi F, Agea E, Bistoni O, Forenza N, Monaco A, Bassotti G, Nicoletti I, Riccardi G, Grignani F, Bertotto A. Increased allergen specific steroidsensitive $\gamma \delta$ T-cells in bronchoalveolar lavage fluid from patients with asthma. Ann Intern Med 1996; 124: 223-227.
19. Agostini C, Chilosi M, Zambello R, Trentin L, Semenzato G. Pulmonary immune cells in health and disease lymphocytes. Eur Respir J 1993; 6: 1378-1401.

20. Fajac I, Roisman GL, Lacronique J, Polla B, Dusser DJ. Characterization of $\mathrm{T}$ cell receptor expression by bronchial T lymphocytes in asthma. Am J Respir Crit Care Med 1994; 149: A955 [abstract].

21. Pawankar R, Okuda M, Suzuki K, Okumura K, Ra C. Phenotypic and molecular characteristics of nasal mucosal $\gamma \delta$ T-cells in allergic and infectious rhinitis. Am J Respir Crit Care Med 1996; 153: 1655-1665.

22. Janis EM, Kaufmann SHE, Scharzi RJ, Pardoll DM. Activation of T-cells in the primary immune response to Mycobacterium tuberculosis. Science 1989; 339: 544-548.

23. Modlin RL, Primez C, Hofman FM, Torigian V, Bloom BR, Brenner MB. Lymphocytes bearing antigen-specific $\gamma \delta$ T-cell receptors accumulate in human infectious disease lesions. Nature. 1989; 339: 544-548.

24. Testi R, D'ambrosio D, De Maria R, Santoni A. The CD69 receptor: a multipurpose cell-surface trigger for hematopoietic cells. Immunol Today 1994; 15: 479-483

25. Romagnani S, Del Preta GF, Maggi E, Ricci M. Th1 andTh 2 cells and their role in disease. Allergy Clin Immunol News 1993; 5: 19-22.

26. Street NE, Mosmann TR. Functional diversity of T-lymphocytes due to secretion of different cytokine patterns. FASEB J 1991; 5: 171-177.

27. Okuda M. Functional heterogeneity of airway mast cells. Allergy 1999; 54: $50-62$.

28. Nakazawa T, Agematsu K, Yabuhara A. Later development of Fas ligandmediated cytotoxicity as compared with granule-mediated cytotoxicity during the maturation of natural killer cells. Immunology 1997; 92: $180-187$.

29. Ashara H, Hasumuna T, Kobata T, Yagita H, Okumura K, Inoue H, Gay S, Sumida T Nishioka K. Expression of Fas antigen and Fas ligand in the rheumatoid synovial tissue. Clin Immunol Immunopatbol 1996; 81: 27-34.

30. Korsgren M, Persson CG, Sundler F, Bjerke T, Hansson T, Chambers BJ, Hong S, Van Kaer L, Ljunggren HG, Korsgren O. Natural killer cells determine development of allergen-induced eosinophilic airway inflammation in mice. J Exp Med 1999; 189: 553-562

31. Grossi CE, Ciccone E, Migone M, Bottino C, Zarcone D, Mingari MC, Ferrini S, Tambussi G, Viale O, Casorati G. Human T cells expressing the $\gamma \delta$ T-cell receptor (TCR-I): $\mathrm{C} \gamma-1$ and $\mathrm{C} \gamma$-2-encoded forms of the receptor correlate with distinctive morphology, cytoskeletal organization, and growth characteristics. Proc Natl Acad Sci USA 1989; 86: 1619-1623.

32. Moretta L, Ciccone E, Mingari MC, Zeromski J, Bottino C, Ferrini S, Tambussi G, Melidi G, Grossi CE, Moretta A. Phenotypic and functional characterization of human T Lymphocytes expressing $\gamma \delta$ T-cell antigen receptor. Clin Exp Rbumatol 1989; 7/S: 9-14.

33. Baron JL, Madri AJ, Ruddle NH, Hashim G, Janeway CA Jr. Surface expression of $\alpha 4$ integrin by CD4 T cells is required for their entry into brain parenchyme. J Exp Med 1993; 177: 57-68.

34. Meliconi R, Ptizalis C, Kingsley GH, Panayi GS. $\gamma \delta \mathrm{T}$ cells and their subpopulation in blood and synovial fluid from rheumatoid arthritis and spondylarthritis. Clin Immunol Immunopathol 1991; 59: 165-172.

35. Hamzaoui K, Hamzaoui A, Hentati F, Kahan A, Ayed Kh, Chabbou A, Ben Hamida M, Hamza M. Phenotype and functional profile of $\mathrm{T}$ cells expressing $\gamma \delta$ receptor from patients with active Beh et's disease. $J$ Rbeumatol 1994; 21: 2301-2306.

36. Morada T, Iiai T, Suzuki S, Tsukahara A, Tada T, Nose M, Hatakeyama K, Seki $\mathrm{S}$, Akeda $\mathrm{H}$, Watanabe $\mathrm{H}$, Abo T. Autologous killing by a population of intermediate T-cell receptor cells and its $\mathrm{NK} 1.1^{+}$and $\mathrm{NK} 1.1^{-}$subsets, using Fas ligand/Fas molecules. Immunology 1997; 91: 219-226.

\section{Received 7 November 2001 \\ Accepted 12 February 2002}




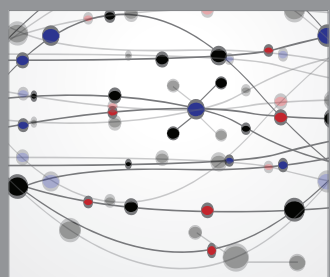

The Scientific World Journal
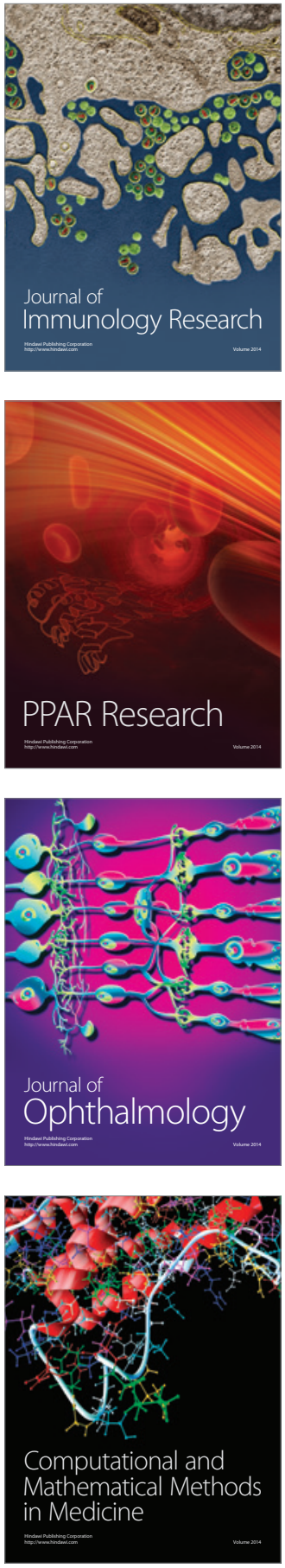

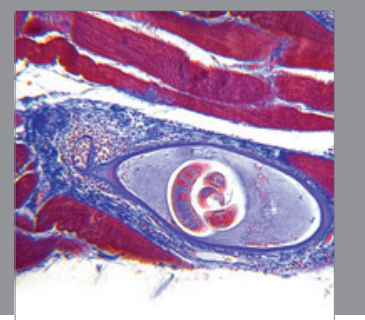

Gastroenterology

Research and Practice
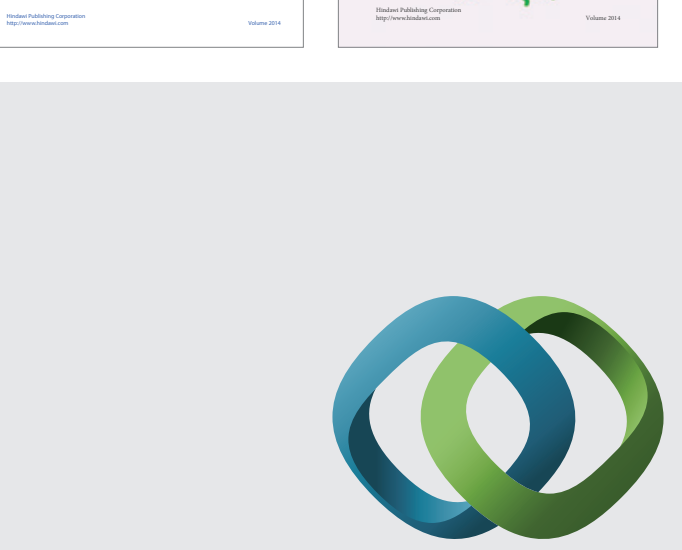

\section{Hindawi}

Submit your manuscripts at

http://www.hindawi.com
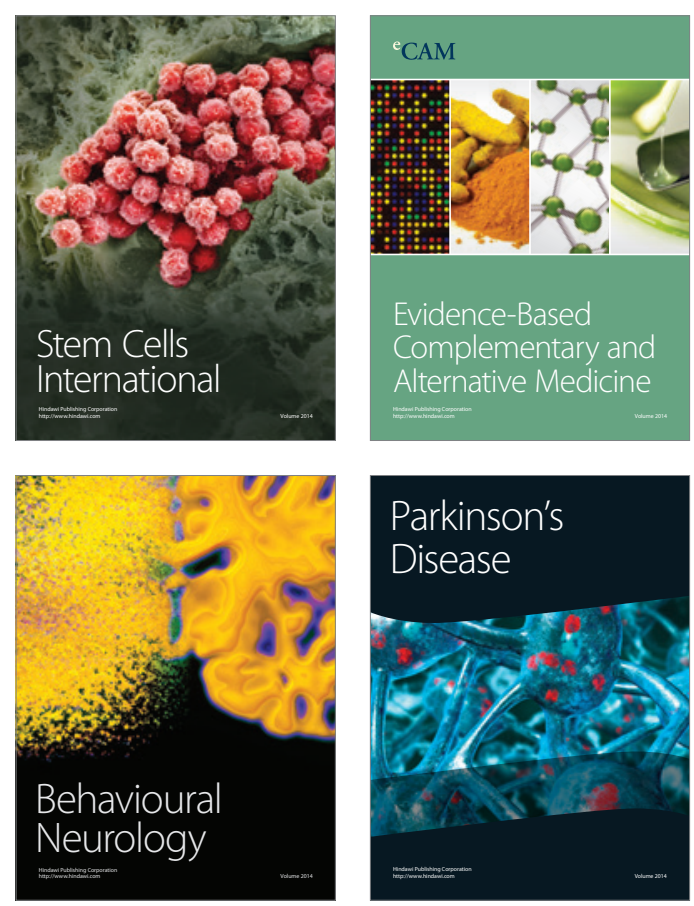

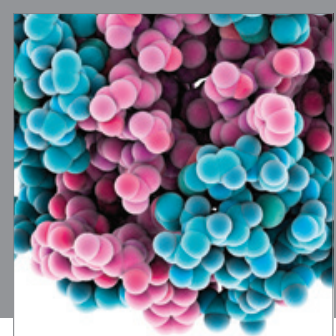

Journal of
Diabetes Research

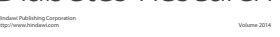

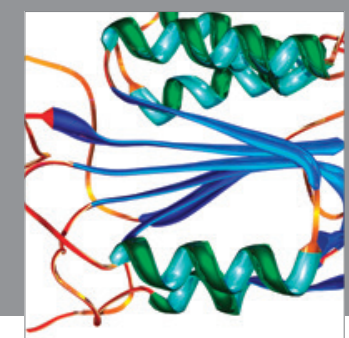

Disease Markers
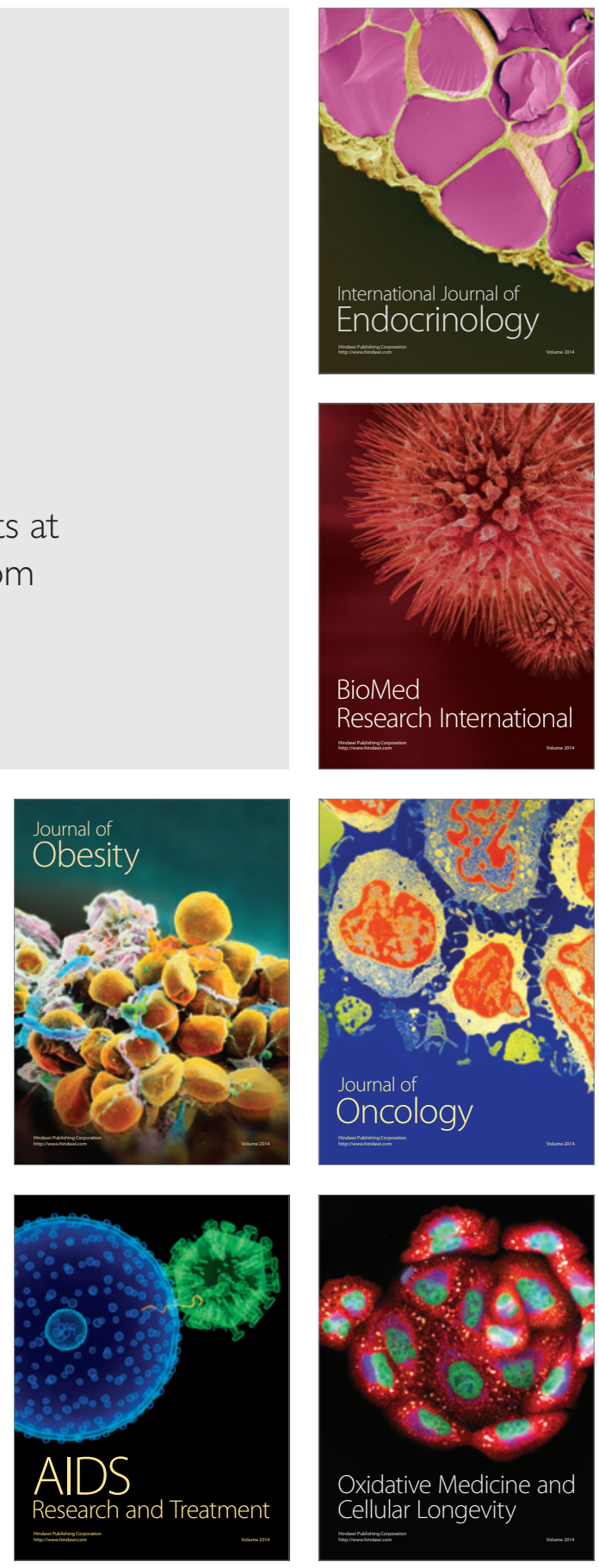